\title{
A EXCEPCIONALIDADE ESTÉTICA: AGENCIAMENTO E PRODUÇÃO DE MUNDOS
}

\author{
THE AESTHETIC EXCEPTIONALITY: AGENCEMENT AND THE \\ MAKING OF WORLDS
}

Antonio Barros de Brito Junior (UFRGS)

antbarros@gmail.com

\begin{abstract}
RESUMO: Este texto é um exercício heurístico em torno dos múltiplos agenciamentos da experiência literária, através da discussão sobre a excepcionalidade estética e a posição do sujeito na experiência artística. Começamos por discutir como a noção de sujeito orientou as abordagens estéticas, tornando a arte uma espécie de fatiche que coaduna com a metafísica ocidental que supostamente serve de referência estável para o pensamento sobre o mundo. Depois, redefinindo o papel do sujeito na experiência estética, avançamos no sentido de entender a obra de arte e a obra literária como objetos que especulam e experimentam sobre o plano da imanência. Assim, a excepcionalidade estética reside não na sua posição intermediária frente ao mundo "real", mas sim na sua posição absolutamente originária em relação ao infinito agenciamento de mundos (cosmovisões). Finalmente, o artigo termina com elucubrações acerca dos agenciamentos no plano da imanência e em como a literatura se liga a esse tipo de experiência.
\end{abstract}

PALAVRAS-CHAVE: estética; sujeito; agenciamento; imanência.

ABSTRACT: This text is a heuristic account of the many arrangements (or agencements) of the literary experience through the debate over the aesthetic exceptionality and the position of the subject in artistic experience. It starts by discussing how the concept of subject guided the different aesthetic approaches in literary and aesthetic theory, turning art into some sort of fatiche which incorporates itself into the Western metaphysics that allegedly works as a static reference for the thinking of the world in which we live in. Then, after redefining the role of the subject in the aesthetic experience, the paper tries to present works of art as objects that speculate and experiment with the immanence. Thus, the exceptionality of the aesthetics lies in its completely original position regarding the potentially infinite ways of making words (cosmovisions) by means of literary agencements. Finally, the article ends with a reflection on the arrangements or agencements within immanence itself, shedding light on how literature connects itself with this kind of experience. 
KEYWORDS: aesthetics; subject; agencement; immanence.

\section{Introdução}

Há pouco tempo, a ideia de uma pandemia mortal era algo que pertencia aos livros de história ou, na melhor das hipóteses, às distopias literárias ou cinematográficas, muito embora já frequentasse, também, as previsões dos cientistas. Contudo, a pandemia do novo coronavírus embaralhou o tempo: o passado recente tornou-se quase remoto, e o presente se faz cada vez mais futuro quando nos obriga a assimilar as angústias e dificuldades de um porvir torturante. Como disse T.S. Eliot (2018, p. 174) ao final de The Hollow Men: "This is the way the world ends/ Not with a bang but with a whimper.” De fato, a transformação repentina que o vírus promoveu em nossas vidas foi um bom sinal do quanto agentes não humanos podem não só reivindicar sua existência, presença e potência diante do humano, como também podem alterar a própria condição humana no mundo através do seu mero contato com a espécie. Assim, toda uma nova concepção de "fazer mundos" torna-se agora mais urgente - uma que leve em conta justamente os limites que o entronamento do sujeito humano impõe às outras formas de produzir relações na era do Antropoceno (HARAWAY, 2016; TSING, 2015). Nesse momento, portanto, conclama-se a literatura a cumprir o seu papel de guia no fim do mundo; e, ainda que não intencionalmente, a infeliz coincidência entre a chamada da presente revista e a devastação sanitária mundial mostra-se uma oportunidade de se pensar em como os diferentes modos de agenciamento literário, que eventualmente especulam sobre entidades e formas de vida imanentes, produzem mundos alternativos que, a exemplo do "Anti-Narciso" de Viveiros de Castro, bloqueiam o "tipo de reflexo epistemopolítico" que produz o "outro" nas representações especulares do Ocidente (VIVEIROS DE CASTRO, 2015, p. 23).

Meu ponto de partida, portanto, não poderia ser outro. Como testemunhas oculares do desastre sanitário - que, por sua vez, é fruto da catástrofe ecológica e do esgotamento dos recursos impostos pelo meio de produção capitalista -, assistimos basbaques à ruina do que nos nossos parâmetros ocidentais poderíamos chamar de "mundo". Curiosamente - et pour cause -, renova-se a fé na liturgia modernista e capitalista, dobrando-se a aposta nas práticas econômicas, sociais e políticas a fim de interromper a "queda do céu" ocidental, seja apelando para o aceleracionismo tecnológico, seja reiterando políticas públicas ambiguamente 
repressivas sob o justo pretexto de controle sanitário da contaminação. ${ }^{1}$ Porém, isso não debela a sensação da presença apocalíptica que nos invade e espreita, provocando uma angústia difusa na medida em que as certezas, as práticas, as formas de sociabilidade e trabalho, os produtos, as vestimentas, as distâncias e os deslocamentos redefinem-se ao som de um lamentoso réquiem. As antigas relações com os objetos, as pessoas, a natureza, a cidade, as tecnologias etc. dão lugar, agora e cada vez mais, a novas formas de interação, de modo que, concomitantemente com a sensação de perda do mundo, experimentamos o surgimento, sem otimismo, de uma nova ecologia ${ }^{2}$ das práticas e dos saberes, que acrescenta conhecimentos e modos de existência àqueles que de fato já são dados pela realidade vivida, sem qualquer projeção de uma consciência ou mente transcendental. Para alguns, porém, o cenário é de perda: o mundo está acabando, se é que já não acabou...

Porém, é preciso afirmar: o mundo não acaba; o que acaba são os mundos. No aparente paradoxo dessa afirmação - e por trás do jogo de palavras -, reside uma convicção: a de que este mundo que perdemos, bem como o mundo que possivelmente está em gestação, responde por apenas um modo de ser-no-mundo e um modo de fazer mundo. O que se sabe desde sempre (e que a metafísica europeia tentou por força escamotear) é que a capacidade humana para criar mundos é potencialmente infinita - algo que se comprova na abundante etnografia disponível (cf., por exemplo, KOPENAWA; ALBERT, 2015; CESARINO, 2013;

\footnotetext{
${ }^{1}$ Em relação a esse debate, recomendo particularmente o livro de Benjamin Bratton (2021), que discute, com base nas manifestações inoportunas de Giorgio Agamben, os novos parâmetros de uma política pós-pandêmica, reconfigurando o sentido dado ao termo biopolítica, na sua origem foucaultiana e na acepção agambiana: "The post-pandemic politics I describe is one that is inclusive, materialist, restorative, rationalist, and based on a more demystified image of human species, anticipating a future different from the one prescribed by many cultural traditions. It accepts the evolutionary entanglement of mammals and viruses. It accepts death as part of life. It therefore accepts responsibilities of medical knowledge to prevent and mitigate unjust deaths and misery, as something quite different from the nativist immunization of one population of people from another. [...] Laissezfaire vitalism for which 'life will find way' is not an option; it is a fairy tale. Similarly, pretending that biopower should not exist, and that choices concerning what does and does not live can be evaded because they are difficult and disturbing, is ultimately another way of allowing biopower to be exercised without accountability" (BRATTON, 2021, p. 5).

${ }^{2}$ Esse conceito é pensado no sentido de Stengers (2010, p. 32-33, destaque da autora), que o define assim: "[...] the term 'ecology' has a dual meaning, 'scientific' and 'political'. Whatever the interdependence among populations of living beings may be, it can be called 'ecological' in the scientific sense by its association with the concerns and research practices of scientific ecology. By analogy we can characterize the population of our practices, as such, as an ecological situation, regardless of the 'immanent mode of existence' of each member or the nature of the contribution represented by the existence of other members for them. In contrast, for those ecologists whose commitment falls within a political register, not all 'ecological' situations are equal, especially when they include members of human species among their protagonists. Ecological practice (political in the broad sense) is then related to the production of values, to the proposal of new modes of evaluation, new meanings. But those values, modes of evaluation, and meanings do not transcend the situation in question, they do not constitute its intelligible truth. They are about the production of new relations that are added to a situation already produced by a multiplicity of relations. And those relations can also be read in terms of value, evaluation, and meaning."
} 
POPOL VUH, 2019). Nas relações com os demais seres habitantes da Terra, assim como na criação de conceitos e objetos, nós, os humanos, não cessamos de produzir e habitar cosmologias (inclusive habitar-produzindo). Mesmo a cosmologia moderna, que promove a divisão entre o reino natural e o reino moral, não escapa a isso, como Bruno Latour (1994) bem o demostra. A existência e a efetividade dessa cosmologia são determinadas por "modos de existência" (SOURIAU, 2020) cuja contingência não escapa aos perigos da própria aniquilação do humano frente às suas diferentes práticas e interações com esse mundo. Bem por isso, talvez o Ocidente esteja provando um pouco daquilo que os povos tradicionais ao redor do globo, e em particular na América pós-colombiana, vivenciaram. Mundos se perdem, portanto, e infelizmente com mais naturalidade do que estamos aptos a admitir.

Por outro lado, mundos se criam, muitas vezes sobre os escombros de outros mundos. Atualizando as relações interindividuais, sociais e políticas entre os membros de uma comunidade, criando novas categorias inclusivas para entidades desprovidas de reconhecimento, fundando outros saberes e promovendo novas tecnologias que preconizam toda uma diferente abordagem das interações recíprocas entre os seres e o seu próprio meio, o que se nota é que a materialidade da vida não impõe a sua realidade limitadora às cosmologias - o que não necessariamente redunda num construtivismo tout court. Assim, por exemplo, sobre a devastação florestal, sobre a destruição nuclear, em torno do acidente radioativo, no corrente de uma pandemia e ao longo do período de mudança climática, construímos mundos que englobam modos de viver e de atuar, transformando radicalmente os princípios norteadores da economia (da acumulação para a subsistência), da política (do reconhecimento para a cooperação), da ontologia (da substância para a simbiogênese) e da ética (da autonomia para a heteronomia). Trata-se, portanto, de uma arte - as "artes de se viver em um planeta danificado" e assombrado pelos fantasmas das espécies, pessoas, práticas e lugares extintos (TSING; SWANSON; GAN; BUBANDT, 2017). ${ }^{3}$ Nesse ponto, a estética talvez tenha algo a

\footnotetext{
3 “Our era of human destruction has trained our eyes only on the immediate promises of power and profits. This refusal of the past, and even the present, will condemn us to continue fouling our own nests. How can we get back to the pasts we need to see the present more clearly? We call this return to multiple pasts, human and not human, 'ghosts.' Every landscape is haunted by past ways of life. We see this clearly in the presence of plants whose animals seed-dispersers are no longer with us. Some plants have seeds so big that only big animals can carry them to new places to germinate. When those animals became extinct, their plants could continue without them, but they have been unable to disperse their seeds very well. Their distribution is curtailed; their population dwindles. This is an example of what we are calling haunting. [...] As anthropologists, we imagine our talk of ghosts in kinship with communities around the world, Western and non-Western, who offer nonsecular descriptions of the landscape and its hauntings. Rather than an a priori distinction between modern and nonmodern, however, we open our analysis to practical ways of learning what is out there: the past and the present around us" (TSING; SWANSON; GAN; BUBANDT, 2017, pp. G2-G3, destaques dos autores).
} 
acrescentar à superação dos paradigmas modernos e liberais que andaram de mãos dadas com a era das catástrofes. Em especial, ela pode apontar para uma outra compreensão do papel do sujeito nas relações sociais e políticas desencadeadas pelo Antropoceno e suas consequências.

$$
* * *
$$

Chama-me a atenção a forma como a noção de "sujeito" mudou de figura ao longo dos séculos - mesmo que mantendo a sua funcionalidade no que tange ao pensamento correlacionista (MEILLASSOUX, 2008). Ao que parece, houve um deslocamento do sujeito de sua posição transcendental na tradição fenomenológica cartesiana-husserlianaheideggeriana - em que a res cogitans se confronta com a res extensa numa espécie de "envaginamento" autorreflexivo e autodiferencial, que divide o sujeito em um corpo sensível e uma mente que é, ao mesmo tempo, interpretadora das sensações e observadora lógica de seus próprios processos cognitivos ${ }^{4}$ - para a posição foucaultiana do "sujeito assujeitado" isto é, o sujeito que, em confronto com os regimes excludentes da verdade e do saber, faz a experiência de si mesmo através de uma hermenêutica ou estilística que atuam sobre as marcas deixadas (às vezes literalmente) no corpo do indivíduo pelos diferentes dispositivos do poder (FOUCAULT, 2010). Inclusive, na política de hoje, a posição de sujeito não prescinde, aparentemente, de uma relação conflituosa instada pelos regimes de visibilidade e dizibilidade (cf. RANCIÈRE, 1996). Ressalta-se, com isso, mais o sentido de "subalterno" da noção de sujeito (sujet $=$ "súdito"), em lugar de seu enquadramento no regime da norma (por via da ficção do direito) ou no regime metafísico (a conaturalidade do espírito). ${ }^{5}$ Porém, quer me parecer que isso não convém aos desafios políticos e sociais desencadeados pelas catástrofes gestadas no capitalismo avançado e pela iminente "sexta extinção" (KOLBERT, 2015). Nesse sentido, talvez a antropologia esteja ganhando terreno sobre a política e a filosofia, na medida

\footnotetext{
${ }^{4}$ Em última análise, o sujeito não é apenas o que "registra e processa" o dado da realidade, mas sim aquele que pensa a si próprio enquanto processa - a noese husserliana (HUSSERL, 1950). De fato, essa posição repercute a teoria cartesiana do sujeito, bem como está na base de grande parte da ciência moderna. O que nos importa destacar, com isso, é o fato de que, independentemente da contingência, a posição reflexiva do sujeito acerca dos dados da experiência e da experiência que faz de si-mesmo remete sempre a uma posição "exterior" ao fenômeno que, de modo conjuntivo, liga a percepção ao conhecimento através da autodiferencialidade. A facticidade da relação sujeito-mundo é subtraída (ou posta entre parênteses) a fim de que prevaleça, ao menos como a priori, a condição efetiva de interpretação e conhecimento do dado (eidética) por um sujeito transcendental.

5 Embora seja proveitoso lembrar que, no caso da filosofia política contemporânea, a despeito de sua parcialidade, as noções de universalidade ainda permaneçam válidas como categorias definidoras do processo político. Os exemplos da Alain Badiou (1998) e Slavoj Žižek (2001) são, provavelmente, os mais marcantes, muito embora não nos escapem de vista os casos de Jacques Rancière (2014) e Giorgio Agamben (1993).
} 
em que tenta pensar em mundo para além do sujeito. E, juntamente com ela, a literatura (NODARI, 2015), que, para todos os efeitos, ainda é considerada como uma operação fortemente marcada pela ideia de sujeito.

Talvez a virada ontológica seja no fundo uma virada metafísica. Entre a "realidade" as causas e efeitos observáveis no mundo, com suas constantes e invariabilidade, que servem de base, em última análise, para a sustentação das entidades e leis naturais também no nível simbólico e discursivo - e o seu papel dentro de um mundo autoexplicativo e organizado, existe de alguma forma um elemento "criativo" (não necessariamente antrópico, diga-se de passagem, uma vez que animais fazem mundo, por exemplo) que combina a experiência e sua regularidade com uma explicação racional (STENGERS, 2010). Construtivismo multiculturalista ou mistificação iluminista? Nem um, nem outro: trata-se de algo diferente, uma vez que essa operação reconecta de alguma forma a natureza à dimensão propriamente cultural da qual ela não deveria (ou não consegue) sair. A criação do mundo moderno, portanto, deve-se antes à incessante produção daquilo que Latour (2021) vai chamar de fatiches: ${ }^{6}$ contra o fetichismo do pensamento "primitivo" que prolifera entidades mágicas, conferindo-lhes algum tipo de agência no mundo, os ocidentais modernos criaram "objetosfato" que fazem parte de um sistema fixo de referências - portanto supostamente independente do ponto de vista humano -, e cuja natureza é determinada pelas leis irrevogáveis do mundo (físico). Esquecendo-se de que são "fabricados" ou de que suas existências decorrem de uma constituição semelhante àquela que promove o contrato social (LATOUR, 1994), os sujeitos se servem dos fatiches como "gabarito" para as cosmologias, tornando o pensamento ocidental moderno uma espécie de ponto de estabilidade para todo e qualquer pensamento diferencial que reivindica outras relações e outras leis (outras ecologias) com o mundo. Assim, tudo o que viola a constituição do pensamento moderno tende a cair no fetiche, afastando-se do centro estável da ciência.

\footnotetext{
6 "A palavra 'fetiche' e a palavra 'fato' possuem a mesma etimologia ambígua - ambígua tanto para os portugueses quanto para os filósofos das ciências. Mas cada uma dessas duas palavras sublinha simetricamente a nuance inversa da outra. A palavra 'fato' parece remeter à realidade exterior; a palavra 'fetiche', às crenças absurdas do sujeito. Ambas dissimulam, nas profundezas de suas raízes latinas, o trabalho imenso de construção que permite tanto a verdade dos fatos como a do espírito. É essa verdade que devemos desvelar, sem acreditar nas elucubrações de um sujeito psicológico impregnado de devaneios, tampouco na existência exterior de objetos frios e a-históricos que cairiam nos laboratórios vindos do céu. E também sem acreditar na crença ingênua. Juntando as duas fontes etimológicas, chamaremos de fatiche a robusta certeza que permite à prática passar à ação, sem jamais acreditar na diferença entre construção e compilação, imanência e transcendência" (LATOUR, 2021, p. 45).
} 
Desnecessário dizer, então, que a estética, cuja natureza é posta em confronto com a da ciência, avizinha-se, na constituição moderna, do pensamento "mágico" e "relacional" que abriga, em maior ou menor grau, o "fetiche" e seu engodo. Contrariamente a isso, o que alego aqui é que a produção dessa clivagem não pode escapar à lógica da produção de mundos. Essa clivagem não é obviamente uma operação estética; muito pelo contrário, ela é uma operação lógica, dado que, por força de pertencer ao próprio regime das práticas modernas, ao estético é dado um papel secundário na produção de fatiches ou de verdades científicas. Especulativamente metafísica em certo sentido, combinando a realidade da experiência (ou a experiência da realidade) com a intuição "mágica" de uma singularidade irrepetível e incomum, a obra de arte é muitas vezes colocada na ordem do fetiche: quando é levada "a sério demais", ou quando é tratada como agente de transformação psicossocial, ela perde a sua natureza especulativa e mesmo lúdica para tornar-se vicária. Nesse caso, ela substitui a res cogitans por uma espécie de deslumbramento sensível que, ao distanciar-se do "real" (ou do mundo objetivo da constituição científica), aprofunda o nexo com o invisível, o inexplicado, o espectral. Desse ponto de vista, quando a obra de arte é considerada como um objeto distinto do fatiche, ela vira presa de um tipo de "psicologia do estranhamento", devendo, por isso, ser analisada não quanto às suas vinculações com a racionalidade, mas sim quanto ao seu pertencimento à esfera do Unheimliche (FREUD, 2010) - englobando, aí, as diferentes manifestações de um tipo de "pensamento selvagem" (LÉVI-STRAUSS, 1989). Com isso, por assim dizer, a arte se torna "primitiva".

Porém, o que sustenta essa alegação é na verdade a própria existência de um modo de pensar e de um modo de ser "científico" (ou "não-primitivo"): inteiramente dentro das práticas que produzem mundos e que separam esferas de poder (o natural e o humano, mais especificamente), esse pensamento subtrai-se da condição metafísica cosmológica para colocar-se em outro nível que não aquele da inteligência bricoleuse. A insistência na separação entre dois regimes práticos e de pensamento, um que se dirige para a realidade e outro que se imiscui com a suposta "irracionalidade" do pensamento encantatório, faz com que a obra de arte adquira um estatuto inconveniente. Ela é "ficção", "fabulação" e extrapolação das certezas e das normas e, nesse sentido, é mais inclinada à loucura do que à razão; ao mesmo tempo, contudo, ela faz parte de uma ordem de fenômenos tipicamente humanos (dentro do pensamento estético tradicional e de matriz kantiana, não há obra sem sujeito), derivados da racionalidade humana e, portanto, perfeitamente enquadráveis como fatiches e não fetiches. No momento em que se acrescenta ao mundo das coisas como um 
discurso (fantasioso e livre) sobre ele e no momento em que o pensamento moderno lhe consagra uma disciplina (a Estética, a Teoria da Literatura, ou a Literaturwissenschaft, que seja), a obra de arte adquire o mesmo status daqueles objetos dos quais se pode falar analiticamente e de um ponto de vista intersubjetivo, a partir de obrigações práticas e científicas reconhecidas pela comunidade. O pensamento ocidental cria, assim, um "híbrido" (LATOUR, 1994), em que a objetividade da obra de arte está na sua materialidade significante, ao passo que sua verdade encontra-se alhures, na transposição dessa materialidade em algo simbólico que passa a fazer parte das concepções validadas pela constituição da ciência e do pensamento modernos. Essa transitividade do material estético é o que permite com que possamos falar sobre ele de um lugar que não se confunde com o tipo de "alucinação" ou "encantamento" tipicamente fetichista.

Daí que, do ponto de vista moderno, é preciso cindir a estética, é preciso instrumentalizá-la, mas sempre a subordinando a uma racionalidade que, de alguma forma, não apenas a priva de seus efeitos imediatos, como também, ao modo da lógica da censura (o censor é o único não afetado por aquilo que ele censura nos outros), coíbe ou canaliza o efeito do sensível com o recurso da subjetividade autodiferenciadora que "fica em suspenso" sobre a experiência. O domínio sobre o estético afirma-se, portanto, a partir da sua manipulação e da transformação de seu valor contingente em alguma outra coisa que só o sujeito pode conceber e adquirir. Assim, as obras entram numa cadeia reprodutiva de sentidos entre sujeitos que se mimetizam uns aos outros num horizonte próximo da ideia tardeana da mimese (TARDE, 1890). Situando a arte no regime das "coisas" e, ao mesmo tempo, tirando dela a sua capacidade de construir e organizar mundos, é que se pode organizar melhor a mimese do mundo moderno: a representação desse mundo (de como as “coisas" são e de como as pessoas agem nele etc.) está por isso determinada por operações de extração de sentido que não têm nada a ver com os agenciamentos coletivos que produzem e proliferam os modos de existência. Tudo se reduz aos valores consagrados da utilidade prática e racionalista da cultura moderna e ocidental, de modo que a efetividade da arte é posta sob controle do regime mimético, que neuroticamente lhe diz "daqui você não passa", especialmente e sobretudo porque, quando ela de fato passa (ou seja, quando é utilitária como pode ser o realismo pedagógico lukacsiano ou do romance contemporâneo adorniano), só atravessa a cancela sob a condição de ser ainda "só arte" - isto é, "fetichista", "inócua", "repetitiva" ou "identitária". Ora, é quando aceitamos a indivisibilidade do estético - isto é, ele é um regime que produz mundo, especula, ficcionaliza, retraduz a experiência, abrange a sensibilidade, ao mesmo 
tempo em que orienta e cartografa um devir, na medida em que recupera a potência ativa da projeção da realidade para outras formas de ser-no-mundo (DELEUZE, 1997) -, é que reabilitamos a sua função (cosmo)política (STENGERS, 2010) para os tempos que restam, decididamente afastando o "fetiche" ocidental da "natureza-em-si" do estético, que supostamente pode ser manipulada ao "bel-prazer" pelo sujeito que eventualmente a transforma em fatiche.

Não deixa de ser um paradoxo o fato de que a prática que tira da literatura a sua imediaticidade para transformá-la em algo de transitivo tenha em mente a obstrução da subjetividade - aquela mais radical, contingente, em certo sentido até "ignorante" de si mesma, porque eivada de preconceitos dotados de circunstancialidade, de desejos e apetites que têm a ver com uma história de vida perfunctória - em favor de uma (inter)subjetividade abundantemente autorreflexiva. Esta, orientada para um saber e respaldada por uma instrumentalidade técnica, reintegra a excepcionalidade estética (o fato de não ser um fenômeno natural, mas sim derivado de uma originalidade e uma contingência inegáveis - a obra do autor, no seu contexto) a uma fenomenologia, de modo que, assim, o sujeito que emerge da experiência não está posicionado mais no âmbito da estética, mas sim no âmbito do conhecimento. Aliás, esse sujeito é instado como pré-condicionado, posto que sua posição que se instaura post facto, já que nesses termos a experiência estética envolve necessariamente a recepção ou a fruição - promove uma inversão na temporalidade da experiência a fim de instaurar o a priori da subjetividade (fenomenológica, portanto "vazia", mas, ao mesmo tempo, preenchida pelas categorias do entendimento) capaz de reduzir o estético a uma práxis. Ora, nessa posição, a obra literária nada mais é do que o seu negativo: uma vez e sempre atestada como fenômeno, não é na sua persistência e imanência que ela será percebida ou considerada; pelo contrário, é na sua diferença de si a si que ela surge como matéria, expressão, conceito, ideia, valor, que, portanto, podem ser transmitidos de indivíduo a indivíduo. Derridianamente, podemos caracterizar essa peculiaridade como a própria diferensa (DERRIDA, 1991); ${ }^{7}$ porém, do nosso ponto de vista, interessa-nos destacar a operação subjacente: o sujeito, que na estética moderna perpassa toda a obra de arte - quer como alma, estilo, direito autoral etc. -, é cindido por essa mesma operação que lhe confere seu estatuto ontológico. Já de cara a obra não será mais do sujeito; ela própria será “objeto",

\footnotetext{
${ }^{7}$ Prefiro utilizar a grafia diferensa para traduzir o neologismo derridiano que transforma a palavra différence, em francês, no neologismo différance, a fim de marcar graficamente uma diferença que não é sensível no plano vocálico. O mesmo acontece em português ao se substituir o $C$ pelo $S$.
} 
oferecida ao pensamento e à consciência não mais como "obra de quem", mas como "fenômeno" autodiferencial (assim como o sol "não é de ninguém", tampouco pode ser o Dom Quixote). Em seguida, porém, é preciso devolver a ela um sujeito, cuja peculiaridade não se sustenta nas limitações de um corpo contingente, afetado - não interessa à literatura proliferar sujeitos, pois, no final das contas, não há qualquer possibilidade de transitividade do conhecimento literário para fins práticos sem o postulado de uma regularidade do sentido e das relações de causa e efeito. O sujeito que surge é, portanto, aquela mesma substância cartesiana capaz de elaborar o conhecimento, isolando o elemento contingente (afectivo) e replicando o elemento "objetivo" e conceitual, reduplicando, com isso, sua própria posição ao longo da infinita temporalidade por sobre a qual se desdobra a consciência crítica. Eis o que chamamos aqui de "milagre da mimese".

Pouco importa se, no bojo da prática crítica, o sujeito se engaje justamente na afirmação de uma diferença. No limite, preserva-se, no argumento, a equivalência do sujeito, não mais entendido como transcendental (chamemo-lo "homem branco europeu"), mas sim como politicamente relevante: em que pese sua especificidade de sujeito histórico assujeitado por violências e marcado pelas diferenças culturais que engendram os vários papeis sociais nas lutas cotidianas por reconhecimento, ainda assim, no estético, a operação almeja um tipo de experiência cuja concretude, sendo relativa a um segmento, tem, no entanto, um valor identitário que dá lastro à consciência-de-si no mundo. Ser sujeito é, nesse sentido, pertencer a um grupo, e o pertencimento, nesse caso, se faz a contrapelo do nomadismo desterritorializante da "literatura menor" (DELEUZE; GUATTARI, 2003). Ao contrário, é um pertencimento que se busca ao reivindicar o que efetiva e afetivamente, alegórica e mimeticamente, se cristaliza como o "objetivo" na estética, ou seja, o perfeito correlato da experiência histórica e pretensamente universal do sujeito. Em outros termos, o sujeito erigese sobre o postulado insuprimível de que ele não "faz mundos", ao menos não no sentido construtivista moderado que adotamos aqui (STENGERS, 2010); em vez disso, ele se projeta no mundo, que é dado como um plano de referências mais ou menos consensual sobre o qual o sujeito se desloca.

$* * *$

O sujeito representado na obra, que por sua vez o representa na realidade, não é necessariamente um sujeito livre e emancipado. Fredric Jameson (1972) acusava o 
estruturalismo e o formalismo russo (chamando-os de "prison-house of language") de terem capturado a realidade e a dialética numa metalinguagem superlativa, capaz de construir uma epistemologia dos fatos linguísticos e literários através de uma recursividade total da linguagem e dos sistemas, excluindo, daí, tanto a posição radicalmente subjetiva do analista quanto a especificidade histórica do objeto estético. Na visão de Jameson, o mundo (ou o real), alienado, entrava na semiótica como representação provida de valor simbólico por força da estrutura, radicalizando a posição pretensamente objetiva do sistema, ao mesmo tempo em que se perdia a dimensão prática da vida. Talvez seja a hora de torcer mais um pouco o parafuso e falar em literatura (ou em estética, de modo geral) como efeito e não como representação. Assim, de um lado estamos consagrando a objetividade mesma da obra não exatamente dentro de um sistema fechado (nem o estruturalismo, nem tampouco a "literatura como sistema"), mas sim como um bloco de sensações (DELEUZE; GUATTARI, 1992), isto é, uma materialidade expressiva que, em si mesma, contém e conserva, ao modo do rizoma, intensidades, vetores, qualidades, valores etc. que remetem à indefectível imanência da obra. Com isso, perde força a noção de que o objeto estético - como qualquer objeto fruto de uma consciência "doadora" de sentido - é, por assim dizer, o correlato (a representação) de uma ideia originada da mente de um sujeito, estendida a outros sujeitos que com ela interagem num nível intelectual ou na ordem do sistema. A causalidade presente na dialética da produção e da recepção estética, que prima por uma anterioridade do sujeito sobre a expressividade, dá lugar, então, a uma visão mais elaborada, segundo a qual o estético envolve uma temporalidade difusa, em que sujeito e objeto, expressividade e sentido, conteúdo e forma compartem uma mesma natureza sensível na irredutível contingência do acontecimento estético. Neste caso, o problema passa a ser: o efeito de uma obra é mensurável sem o postulado da "consciência", da "mente" ou da "ideologia", que, entre outros, são critérios decorrentes da filosofia do sujeito para aferir a mudança na realidade prática do acontecimento literário e estético ${ }^{8}$ Como falar em efeito, nesse caso, sem lançar mão, por

\footnotetext{
${ }^{8}$ Não seria essa uma querela parecida com aquela entre Hobbes e Boyle, discutida por Latour (1994, p. 33)? Quando Boyle apelava para testemunhas confiáveis a fim de dar credibilidade aos seus experimentos e, portanto, conferir status de verdade às proposições científicas acerca dos eventos da natureza, ele estava justamente criando uma "jurisdição" onde os fatos "falam por si mesmo", na medida em que declaram o mesmo independentemente do observador - algo que, em última instância, assemelha-se à transcendência mediante a qual Hobbes queria fundar o Estado monárquico. Nesse sentido, postular um efeito contínuo e intersubjetivo, que do material estético alcance uma gama de indivíduos - que, portanto, se alçam à condição de sujeitos na medida em que atuam reflexivamente desde sua posição fenomenológica - e realize alterações específicas (ainda que no "estado de alma" de cada um), é de alguma forma criar um vínculo entre o objetivo (o natural) e o subjetivo (o humano), colocando a obra de arte no lado do fenômeno e o intérprete, no campo do observador ou juiz. Esse
} 
exemplo, de uma epistemologia capaz de circunscrever o(s) sujeito(s) e suas práticas em uma cartografia das posições políticas e papéis sociais que de algum modo predispõe a análise a encontrar as correlações sincrônicas ou diacrônicas entre os diferentes indivíduos implicados na comunicação estética (o autor e sua posição; o leitor e seu lócus social de recepção; as identidades evocadas no plano político da luta por reconhecimento; o texto e sua relação com a tradição literária etc.)? Uma estética calcada no efeito - ou seja, uma analítica que tem que começar de novo e sempre, porque o acontecimento estético supostamente não se espraia sobre a cartografia das posições sociais, nem conserva sua força ao longo do tempo - é sequer concebível? Há aparentemente duas formas de contornar esse problema: a primeira tem a ver com a expressividade e a afecção da obra literária (DELEUZE; GUATTARI, 1992); a segunda diz respeito à noção de agência (GELL, 2018).

Do ponto de vista da filosofia cognitiva, o sujeito racional está onde queremos que ele esteja, ao passo que a emoção está sempre onde de fato estamos (TERADA, 2001). ${ }^{9}$ Como já aludimos, o aspecto autodiferencial do sujeito é o que torna possível a concepção de alguma coisa além da mera experiência, isto é, um "excedente" ontológico que nunca reside na - ou melhor, reside dentro e fora da - experiência, numa espécie de dobra da consciência sobre si mesma. Assim, o sujeito sempre aparece no constante deslocamento entre a cognição e o sensível, entre a transcendência e a imanência. $O$ afeto e a emoção, pelo contrário, correspondem ao aspecto mais vívido e verdadeiramente concreto da existência, que resiste à posição do sujeito na medida em que não se reduz completamente a ele. Quando o elemento afetivo entra em conta, portanto, o sujeito transborda a sua posição central na experiência para encontrar as zonas de vizinhança (DELEUZE; GUATTARI, 1997) que caracterizam o seu pertencimento ao mundo como ente e corpo, na sua capacidade de afetar e ser afetado. Se é assim, resta valorizar esse aspecto afectivo e transformá-lo em uma plataforma concreta sobre a qual se possa construir um modo de existência comum que consiste em sentir-junto (entre humanos e outras espécies), numa sorte de expressivismo sem subjetivismo. Isso é possível, porque não é necessário postular uma subjetividade potencialmente universalizante (um ponto de vista sobre outros pontos de vista) da qual depende a expressividade como forma do

\footnotetext{
vínculo duplo (sujeito-objeto, objeto-sujeito) aprisiona a experiência à legislação imposta pela constituição da metafísica moderna.

9 "A living system is self-differential; experience is experience of self-differentiality. The idea of emotion is as compelling as it is because in the honest moments of philosophy it has served as the name of that experience. On some level everyone knows that rationality may be where we want to be, but emotion is where we are. So when we want to get from where we are to where we want to be, emotion has got to come along" (TERADA, 2001, p. 156).
} 
conteúdo. O que já há no afecto é devidamente expressivo em si, inclusive quando passa por uma cadeia de indivíduos que transformam e são transformados pelas qualidades e intensidades do afecto nas suas próprias relações. É, portanto, uma "filosofia das relações" o que se postula; e também uma estética que não patrocina a divisão entre racional e sensível, afectivo e subjetivo, natural e moral - em outras palavras, a estética e a literatura como cosmovisão.

A excepcionalidade da estética - e consequentemente da literatura - talvez não esteja na sua posição alternativa ao mundo real (posição em que ela é colocada pela filosofia moderna), mas sim na sua condição de remeter sempre ao começo, a uma origem sem essência primeira, ao plano puramente diferencial onde tudo e qualquer coisa se misturam. Não se trata do caos; em vez disso, podemos dizer que se trata da confusão (DELEUZE, 2006). ${ }^{10}$ As obras de arte, portanto, remetem à imanência e ao antilogos. Por sua vez, a expressividade literária não postula um referente relativamente estável, como o da ciência ou do pensamento lógico; pelo contrário, seu referente é o pensamento mesmo, na sua condição de produzir e relacionar, de criar entidades, relações de causalidade, transcendências e exterioridades que, se por um lado não têm contrapartida concreta na realidade, por outro lado apontam para a situação concreta na qual o humano está lançado no mundo. As sensações, afectos e emoções que decorrem da experiência estética e literária não pertencem exclusivamente a ninguém; elas agem, atravessando corpos e os modificando, de modo que se trata da materialidade mesma do estético. O expressivo na literatura não é a metáfora ou a analogia (o jogo de identidades tropológico), mas sim algo da ordem do incorporal (GROSZ, 2017), isto é, qualidades e intensidades que se situam justamente na imanência. Sendo assim, o que importa na experiência literária e estética é o modo como fazemos experiência desse lugar, onde tudo o que existe comunica e toda forma de pensamento e de relação é ainda possível. Em lugar de um ponto de vista único e transcendente, vários pontos de vista móveis, alternados e emaranhados, engendrando pensamentos sobre pensamentos, relações sobre

\footnotetext{
${ }^{10}$ Ao comentar sobre a obra de Proust, Deleuze deixa mais claro esse aspecto da produção literária: "Mas a essência, por sua vez, não é mais a essência estável, a idealidade vista, que reúne o mundo em um todo e nele introduz a justa medida. A essência [...] não é algo visto, mas uma espécie de ponto de vista superior. Ponto de vista irredutível que significa tanto o nascimento do mundo quanto o caráter original de um mundo. Nesse sentido a obra de arte constitui e reconstitui sempre o começo do mundo, mas forma também um mundo específico absolutamente diferente dos outros, e envolve uma paisagem ou lugares imateriais inteiramente distintos do lugar em que o apreendemos. [...] Mas o importante é que o ponto de vista ultrapassa o indivíduo, tanto quanto a essência ultrapassa o estado d'alma: o ponto de vista permanece superior àquele que nele se coloca ou garante a identidade de todos que o atingem. Não é individual, mas, ao contrário, princípio de individuação" (DELEUZE, 2006, p. 104, destaque do autor).
} 
relações, não em metalinguagem, mas na metarreflexão constante, que não deixa de ver a diferença ao mesmo tempo em que se remete a si. Mais do que isso: ao fazer a experiência do literário e do estético, estamos fazendo parte (portanto, experimentando) um tipo de vivência cuja materialidade é profundamente sensível, na medida em que antecede a experiência lógica do mundo. Ali, há a experiência de vários mundos, simultâneos, em que as entidades que o habitam estão em completa correlação (uma correlação diferente do correlacionismo, portanto), pré-individuadas, afetando-se mutuamente.

Eis, pois, a razão por que acredito que a experiência estética e literária nos fala de um lugar originário, que não é, para todos os efeitos, o lugar primeiro: ela está antes do pensamento lógico porque ela é um tipo de pensamento sensível, um mergulho na imanência, um lugar de partida da cosmovisão. Ligada à imanência, a experiência estética e literária é especulativa por força de sua própria inclusão no mundo que ela cria. Ela traciona sobre o incorporal para dele extrair entidades e leis que no fundo são formas de imaginação política mas nunca universais -, na medida em que postulam e redefinem relações e projetam mundos. A excepcionalidade do estético e do literário, portanto, tem a ver com o eterno retorno do pensamento que faz mundos. Extrapolando a espiritualidade existencialista de Blanchot (1997), é possível, portanto, dizer que a literatura nunca começa simplesmente, nem tampouco termina; ela recomeça sempre de um ponto de vista diferencial sobre o plano da imanência, ponto de vista que não faz a extração de si mesmo como sujeito fora desse vínculo com o concreto e as zonas de vizinhança do humano.

Ao fazermos referência à imanência, não apontamos apenas para um plano em que as entidades estão em constante transformação e contato, mas também estamos afirmando que este é um planeta simbiótico (MARGULIS, 1998). ${ }^{11} \mathrm{O}$ contato entre as espécies faz parte,

\footnotetext{
11 "Symbiosis, the system in which members of different species live in physical contact, strikes us as an arcane concept and a specialized biological term. This is because of our lack of awareness of its prevalence. Not only are our guts and eyelashes festooned with bacterial and animal symbionts, but if you look at your backyard or community park, symbionts are not obvious but they are omnipresent. Clover and vetch, common weeds, have little balls on their roots. These are the nitrogen-fixing bacteria that are essential for healthy growth in nitrogenpoor soil. Then take the trees, the maple, oak, and hickory. As many as three hundred different fungal symbionts, the mycorrhizae we notice as mushrooms, are entwined in their roots. Or look at a dog, who usually fails to notice the symbiotic worms in his gut. We are symbionts on a symbiotic planet, and if we care to, we can find symbiosis everywhere. Physical contact is a nonnegotiable requisite for many differing kinds of life" (MARGULIS, 1998, p. 5).
} 
portanto, da toda e qualquer existência no planeta. Isso implica numa retradução da vida em termos distintos da ciência tradicional e da biologia evolutiva darwiniana: na medida em que os organismos coexistem em simbiose, a evolução da espécie não se esclarece da mesma forma, devendo, por isso, ser considerada do ponto de vista de uma coevolução, que abriga, entre outras coisas, intencionalidades ou disposições, ações e reações, que implicam, de algum modo, numa espécie de metamentalidade natural (BATESON, 1986). Algo desse tipo pode ser encontrado nos estudos de etologia - animais fazem metalinguagem quando, por exemplo, usam o seu comportamento instintivo para brincar com seus companheiros de espécie ou outras espécies, como faz o cachorro (MASSUMI, 2017) ou o polvo (GODFREYSMITH, 2019) - e botânica - a "memória da planta" ou sua capacidade sensível de reagir ao contexto e ao ambiente, modificando suas características conforme a necessidade e a sua plasticidade (MANCUSO, 2019). Esses eventos remetem a outra concepção de expressividade através da ideia de agenciamento.

O agenciamento constitui um tipo de metamentalidade que produz algo por acréscimo e justaposição. Diferentemente da noção tradicional de intencionalidade - segundo a qual o produto (a obra de arte, o trabalho, o discurso etc.) é fruto das disposições mentais do sujeito que organiza a expressão a fim de fazê-la coincidir o máximo possível com o conteúdo -, o agenciamento é tipicamente coletivo e transindividual. Nele, as entidades, atuando como forças às vezes pré-individuadas, combinam-se e formam uma materialidade significante cuja expressividade é dotada de múltiplas variáveis. Isso acontece na natureza pela cooperação interespecífica, quando, por exemplo, indivíduos de uma ou mais espécies atuam para formar um território ou um ecossistema. Mas acontece sobretudo nos fenômenos linguísticos portanto, na ordem de eventos mais próxima dos acontecimentos humanos. Se é assim, faz sentido considerar a obra literária como fruto de agenciamentos coletivos.

$\mathrm{Na}$ literatura as coisas estão ligadas pela expressão. O texto não tem um "fora", no sentido de que ele não é uma forma da expressão que faz referência a um conteúdo fixado. Uma obra literária arregimenta em blocos de sensação e de sentido uma variedade potencialmente infinita de agentes, de modo que seu sentido final nunca deixa de ser a sua abertura para a exploração especulativa do leitor. Com isso, a obra literária nunca transcende o seu ponto de vista; ela apenas o reitera, apresentando na sua expressão a possibilidade dessa virtualidade que constantemente se atualiza no acontecimento estético. Portanto, o que o leitor encontra na obra são entidades e relações moventes que, uma vez que entram em contato com o leitor, adquirem a forma de um mundo. $\mathrm{O}$ agenciamento se faz no instante mesmo em que 
há o contato: não há um "compromisso" prévio que predisponha o leitor a aceitar as premissas do texto. O texto, enquanto tal, é apenas mais um elemento que se junta ao leitor - este, envolvido em sua contingência e circundado por uma série de outros elementos que o atravessam e o constituem naquele instante -, de modo que outro agenciamento se cria e assim indefinidamente. Nada detém o agenciamento, nem nada o inicia: no plano da imanência as coisas já se agenciam para formar outras; e, no que tange à produção estética e literária, a obra remonta exatamente a esse lugar em que as coisas estão se agenciando, colocando o leitor como parte disso não de um ponto de vista privilegiado e transcendental que ele alcança por si só ou por princípio, mas sim imiscuído na própria expressividade afectiva constitutiva da materialidade artística. Nesse viés, nada é mais expressivo do que o próprio acontecimento da leitura literária, com seus movimentos inconscientes, maquínicos, afectivos, perceptivos, desiderativos etc., que fazem conjunto com a materialidade sensível da linguagem textual.

Nesse sentido, a literatura tem a capacidade de proliferar entidades, relações, regras e princípios. Ela é essa instanciação incessante de algo sempre novo e que se renova no acontecimento estético, em que o agenciamento se faz uma e outra vez. Por não ser uma expressão que se refere necessariamente ao mundo exterior, ela é o seu próprio mundo. E uma vez que também não tem um dentro, ela não "conserva" dentro de si nada além dessa materialidade significante afetiva que faz mundo com o leitor, no agenciamento próprio do acontecimento. E isso não tem nada a ver com os postulados autorreferencialistas da semiótica estrutural e do formalismo de princípios do século XX; tem a ver, antes, com um outro tipo de materialismo que salienta a efetiva concretude das sensações estéticas (um empirismo sofisticado, portanto). Nesses termos, a literatura faz agência, transforma, modifica, reproduz e replica conhecimentos sobre o mundo e sobre fazer mundos. Mas ela não o faz ao modo da relação mestre-discípulo; ela não "ensina”, pois não há um "conteúdo" com o qual o sujeito pode se satisfazer na sua operação de extração de sentido. Sendo um acontecimento, ela se prende à contingência absoluta - e não há, na filosofia tradicional, pensamento lógico ou científico que possa prescindir da necessidade em proveito da contingência, como de alguma forma nos mostra Meillassoux (2008), a despeito de sua própria tentativa.

Por isso, vale a pena refletir se a experiência dos múltiplos agenciamentos da literatura não se daria na forma de uma antropologia da arte, cujo principal intuito é compreender as formas de interação dos indivíduos com as práticas e sensações derivadas do acontecimento 
estético. Na medida em que, como vimos, há algo de circular no agenciamento e na posição do estético em relação ao pensamento sobre o mundo, pensar o efeito estético do ponto de vista de uma espécie de "ritualismo" pode nos ajudar a compreender o modo pelo qual as obras de arte - e as obras literárias, sobretudo - ainda têm um papel a cumprir na mudança deste mundo, contrariando e combatendo os efeitos deletérios do capitalismo no Antropoceno. No fundo, é preciso pensar em como somos agentes e pacientes, ao mesmo tempo, das obras e de sua circulação (GELL, 2018) - ou seja, como o contato que faz mundo também transforma o mundo. Isto é, o nosso contato com as obras de arte e os textos literários pode não formar uma consciência efetiva acerca dos danos e dos perigos do capitalismo avançado nas suas diferentes formas de catástrofe. Por outro lado, talvez não haja, na estética moderna, um exemplo de obra-fatiche que tenha sido capaz de alterar visivelmente as nossas disposições de espírito para com o planeta. Pelo contrário, parece-me que a ilusão modernista propagou, através do mercado consumidor da arte, uma forma mais ou menos instintiva de reduzir o estético ao "anódino", como vimos acima. Nesse sentido, talvez, recuperar a noção de agência tem o proveito não de repor a questão da consciência em termos de escala - caracterizada na pergunta formulada mais ou menos assim pelos estudos literários ocupados com a política da estética: “a arte pode mudar o mundo?" -, porque o mundo, tal como entendido pela constituição moderna, é um lugar grande demais para ser mudado por uma só e definitiva prática. Porém, se pensarmos na literatura como um modo de produzir mundos na contingência insuprimível do acontecimento estético, então talvez possamos recuperar um certo sentido "litúrgico" do contato e da agência artística: a propagação não mais de uma consciência formada (por) sobre o mundo, mas a propagação, por contato real e sempre reiterada, de um horizonte de transformação que abriga o estético, em vez de ser determinado por ele. Pessimisticamente, talvez, não há “impulso" para fora do estético, porque esse salto limita-se quase sempre a alcançar os âmbitos do espírito prático do sujeito transcendental. Otimisticamente, porém, é esse retorno para a excepcionalidade estética tal como defendida aqui que vai nos ajudar a formar mundos (pequenos, frágeis e precários, quem sabe?) quando este estiver irremediavelmente perdido... 


\section{REFERÊNCIAS}

AGAMBEN, Giorgio. A comunidade que vem. Tradução de Antonio Guerreiro. Lisboa: Editorial Presença, 1993.

BADIOU, Alain. Compêndio de metapolítica. Meditações filosóficas. v. III. Tradução de Filipe Duarte. Lisboa: Instituto Piaget, 1998.

BATESON, Gregory. Mente e natureza. A unidade necessária. Tradução de Claudia Gerpe. Rio de Janeiro: Francisco Alves, 1986.

BLANCHOT, Maurice. A literatura e o direito à morte. In: BLANCHOT, Maurice. A parte do fogo. Tradução de Ana Maria Scherer. Rio de Janeiro: Rocco, 1997. p. 289-330.

BRATTON, Benjamin. The Revenge of the Real. Politics for a Post-pandemic World. Londres e Nova York: Verso, 2021.

CESARINO, Pedro de Niemeyer. Quando a Terra deixou de falar. Cantos da mitologia marubo. São Paulo: Editora 34, 2013.

DELEUZE, Gilles; GUATTARI, Félix. Devir-intenso, devir-animal, devir-imperceptível. In: DELEUZE, Gilles; GUATTARI, Félix. Mil platôs: capitalismo e esquizofrenia. v. 4. Tradução de Suely Rolnik. São Paulo: Editora 34, 1997. p. 11-113.

DELEUZE, Gilles; GUATTARI, Félix. Kafka, para uma literatura menor. Tradução de Rafael Godino. Lisboa: Assírio e Alvim, 2003.

DELEUZE, Gilles; GUATTARI, Félix. O que é a filosofia?. Tradução de Bento Prado Jr. E Alberto Alonso Muñoz. São Paulo: Editora 34, 1992.

DELEUZE, Gilles. Crítica e clínica. Tradução de Peter Pál Pelbart. São Paulo: Editora 34, 1997.

DELEUZE, Gilles. Proust e os signos. Tradução de Antonio Carlos Piquet e Roberto Machado. Rio de Janeiro: Forense Universitária, 2006.

DERRIDA, Jacques. A diferença. In: DERRIDA, Jacques. Margens da filosofia. Tradução de Joaquim Torres Costa e Antonio M. Magalhães. Campinas: Papirus, 1991. p. 33-63.

ELIOT, T.S. The Hollow Men. In: ELIOT, T.S. Poemas. Tradução de Caetano W. Galindo. Edição bilíngue. São Paulo: Companhia das Letras, 2018. p. 165-175.

FOUCAULT, Michel. A ordem do discurso. Aula inaugural no Collège de France pronunciada em 2 de dezembro de 1970. Tradução de Laura Fraga de Almeida Sampaio. São Paulo: Edições Loyola, 2010.

FREUD, Sigmund. O Inquietante. In: FREUD, Sigmund. História de uma neurose infantil ("O Homem dos Lobos"), Além do princípio do prazer e outros textos. Obras completas. v. 14. Tradução de Paulo César de Souza. São Paulo: Companhia das Letras, 2010. p. 328-376. 
GELL, Alfred. Arte e agência. Uma teoria antropológica. Tradução de Jamille Pinheiro Dias. São Paulo: Ubu Editora, 2018.

GODFREY-SMITH, Peter. Outras mentes: o polvo e a origem da consciência. Tradução de Paulo Geiger. São Paulo: Todavia, 2019.

GROSZ, Elizabeth. The incorporeal. Ontology, Ethics, and the Limits of Materialism. Nova York: Columbia University Press, 2017.

HARAWAY, Donna. Staying with the Trouble. Making Kin in the Chthulucene. Durham e Londres: Duke University Press, 2016.

HUSSERL, Edmund. Idées directrices pour une phénoménologie. Tradução francesa de Paul Ricoeur. Paris: Gallimard, 1950.

JAMESON, Fredric. The Prison-house of Language. A Critical Account of Structuralism and Russian Formalism. Princeton: Princeton University Press, 1972.

KOLBERT, Elizabeth. A sexta extinção. Uma história não natural. Tradução de Mauro Pinheiro. Rio de Janeiro: Intrínseca, 2015.

KOPENAWA, Davi; ALBERT, Bruce. A queda do céu. Palavras de um xamã yanomami. Tradução de Beatriz Perrone-Moisés. São Paulo: Companhia das Letras, 2015.

LATOUR, Bruno. Jamais fomos modernos. Ensaio de antropologia simétrica. Tradução de Carlos Irineu da Costa. São Paulo: Editora 34, 1994.

LATOUR, Bruno. Sobre o culto moderno dos deuses fatiches. Seguido de Iconoclash. Tradução de Sandra Moreira e Rachel Meneguello. São Paulo: Editora Unesp, 2021.

LÉVI-STRAUSS, Claude. A ciência do concreto. In: LÉVI-STRAUSS, Claude. $O$ pensamento selvagem. Tradução de Tânia Pellegrini. Campinas: Papirus, 1989. p. 15-50.

MANCUSO, Stefano. Revolução das plantas: um novo modelo para o futuro. Tradução de Regina Silva. São Paulo: Ubu Editora, 2019.

MARGULIS, Lynn. Symbiotic planet. A new look at evolution. Nova York: Basic Books, 1998.

MASSUMI, Brian. O que os animais nos ensinam sobre política. Tradução de Francisco Trento e Fernanda Mello. São Paulo: n-1 edições, 2017.

MEILLASSOUX, Quentin. After Finitude. An Essay on the Necessity of Contingency. Tradução inglesa de Ray Brassier. Nova York: Continuum, 2008.

NODARI, Alexandre. A literatura como antropologia especulativa. Revista da Anpoll, Florianópolis, n. 38, p. 75-85, jan./jun. 2015.

POPOL VUH. O esplendor da palavra antiga dos Maias-Quiché de Quauhtlemallan: aurora sangrenta, história e mito. Tradução de Josely Vianna Baptista. São Paulo: Ubu Editora, 2019. 
RANCIÈRE, Jacques. Nas margens do político. Tradução de Vanessa Brito e João Pedro Cachopo. Lisboa: KKYM, 2014.

RANCIÈRE, Jacques. $O$ desentendimento. Política e filosofia. Tradução de Ângela Leite Lopes. São Paulo: Editora 34, 1996.

SOURIAU, Étienne. Diferentes modos de existência. Tradução de Walter Romero e Menon Júnior. São Paulo: n-1 edições, 2020.

STENGERS, Isabelle. Cosmopolitics I. Tradução inglesa de Robert Bononno. Mineápolis e Londres: University of Minnesota Press, 2010.

TARDE, Gabriel. Les lois de l'imitation. Paris: Félix Alcan, 1890.

TERADA, Rei. Feeling in theory. Emotion after the "Death of the Subject". Cambridge e Londres: Harvard University Press, 2001.

TSING, Anna Lowenhaupt. The Murshroom at the End of the World. On the Possibility of Life in Capitalist Ruins. Princeton: Princeton University Press, 2015.

TSING, Anna; SWANSON, Heather; GAN, Elaine; BUBANDT, Nils (orgs.). Arts of Living on a Damaged Planet. Ghosts of the Anthropocene. Mineápolis e Londres: University of Minnesota Press, 2017.

VIVEIROS DE CASTRO, Eduardo. Metafísicas canibais. Elementos para uma antropologia pós-estrutural. São Paulo: Cosac Naify e n-1 edições, 2015.

ŽIŽEK, Slavoj. El espinoso sujeto. El centro ausente de la ontologia política. Tradução espanhola de Jorge Piatigorsky. Buenos Aires, Barcelona, México DF: Paidós, 2001.

Submetido em: 03 nov. 2021.

Aceito em: 03 nov. 2021.

DOI: https://dx.doi.org/10.22456/2238-8915.119738 